\title{
Türkiye'de Sinemayı Konu Alan Doktora Tezleri Üzerine Bibliyometrik Bir Çözümleme
}

\author{
Yrd. Doç. Dr. Çağrı inCEOĞLU
}

yaşar üniversitesi iletişim fakültesi radyo, televizyon ve sinema bölümü

cagri.inceoglu@yasar.edu.tr

\begin{abstract}
A Bibliometric Analysis on the Cinema Studies Doctoral Theses in Turkey

Postgraduate theses provide valuable data to ascertain the characteristics and tendencies of research in an academic field. In this research, 199 doctoral theses that have been completed between 1985 and 2013 (Turkey) in cinema studies analysed through a bibliometric method according to a series of specifications such as the number of theses per year, the disciplines which the doctoral study is undertaken, research topics, critical and theoretical bases, examined production types, geographical focus, language, and keywords. The conclusion points that while the quantity of doctoral theses has increased dramatically, sociological approach has gained importance. Moreover, Turkey's cinema has become a common topic among the doctoral researches.
\end{abstract}

keywords: bibliometrics, cinema, film studies, cinema studies, theses 


\section{Résumé}

\section{Une analyse bibliométrique des thèses de doctorat sur le cinéma en Turquie}

Les thèses des études supérieures représentent des données très importantes dans une recherche universitaire pour déterminer les caractéristiques d'orientations. Dans cette étude, 199 thèses de doctorat réalisées en Turquie entre 1985 et 2013 sur le cinéma ont été traités par l'analyse bibliométrique en fonction des départements disciplines dans lesquels elles ont été réalisées, des sujets de recherche fondamentale, les fondements critiques et théoriques, des types de construction, de la langue de rédaction et des mots-clés. Certains résultats de la recherche démontrent que le nombre de thèses sur le cinéma a augmenté ces dernières années, que l'interdisciplinarité est en hausse, que la perspective sociologique a une grande importance, et que les recherches se concentrent de plus en plus sur le cinéma turc.

mots-clés : bibliométrie, cinéma, recherches sur le cinéma, thèses

\section{Özet}

Lisansüstü tezleri bir akademik alandaki araștırmaların özelliklerini ve yönelimlerini tespit edebilmede önemli veriler sunmaktadır. Bu çalışmada, 1985-2013 yılları arasında Türkiye'de sinema konusunda tamamlanmış 199 doktora ve sanatta yeterlilik tezi yıllara göre sayısal değişimleri, bağlı oldukları anabilim ve anasanat dalları, temel araştırma konuları, dayandıkları eleştirel ve kuramsal arkaplan üzerine eğildikleri yapım türleri, bölge sinemaları ile yazıldıkları diller ve içerdikleri anahtar kelimeler açısından bibliyometrik çözümlemeye tabi tutulmuştur. Araştırma sonuçlarından bazıları göstermektedir ki tez sayısı son yıllarda ciddi bir biçimde artarken disiplinler arasılık özelliği yükselmekte, toplumbilimsel bakış açısı önem kazanmakta, ayrıca Türkiye sineması günden güne araştırmalarda daha fazla yer almaktadır.

anahtar kelimeler: bibliyometri, sinema, sinema araştırmaları, tezler 


\section{Giriş}

Akademik bir alan olarak sinema araştırmalarının tarihçesi yakın bir geçmişe sahiptir. Dünyada ilk olarak 1950'lerin sonlarında üniversite çatısı altında sinema araştırması ve eğitimi yapılması düşüncesi tartışımaya başlanmıştır (Grieveson 2009: 168). 1960'larda üniversitelerde edebiyat ve dilbilim disiplinleri altında ortaya çıkan ve kendini sinema araştırmaları olarak niteleyen çalışmalar 1970'lerde kurucu metinlerini üreterek (Turner, 1999: 46-47), bağımsız bir disiplin olarak akademide kabul görmüş olmasına karşın literatür son derece sınılı kalmıştır (Altman 2009: 132). Sinema araştırmalarında asıl canlanma 1980 ve 1990'larda ortaya çıkmış, okullaşma artmış, disiplin kendi akademisyen kadrolarını da bu tarihlerden itibaren yetiştirmeye başlamıştır (Altman 2009: 132-134).

Türkiye'de de benzer bir yol izlemiş olan araştırmalar; ilk olarak edebiyat, dilbilim, tiyatro gibi farklı alanlardan gelen akademisyenlerin çalışmalarıyla başlamıştır. Üniversitelerde 1970'li yılların ikinci yarısında başlamış olan sinema eğitimi ile birlikte 1980'li yıllardan itibaren de lisansüstü düzeyde sinema eğitim ve araştırması yapılmaktadır. Bu nedenle, söz konusu yıllardan beri Türkiye'de lisansüstü düzeyde sinema tezleri üretilmeye devam edilmektedir.

Akademik bir alanın gelişimi ve yönelimleri o alanda gerçekleştirilen yayınların ve lisansüstü araştırmaların çözümlenmesi yolu ile tespit edilebilir. Bu tür çalışmalar literatürde bibliyometrik analiz olarak adlandırılırlar. Bibliyometrik yöntemin kullanıldığı çalışmalar aslen on dokuzuncu yüzyılın sonlarına kadar uzanır. Bu yöntem, temelde kütüphanecilerin kullanımı için ortaya çıkmıştır ve asıl gelişimi yirminci yüzyılda olmuştur. 1917'de Cole ve Eales'in 1543-1860 yılları arasında yazıımış anatomi literatürüne ülkelerin katkı oranlarını inceledikleri araştırma ilk bibliyometrik analizler arasında kabul edilmektedir (Narin 1976: 1). Gross ve Gross 1927 'de yaptıkları çalışmada, araştırmalarda yapılan atıfların incelenmesinin bir kütüphanenin yeterliliğini ölçmede önemli bir araç olabileceğini belirtmişlerdir (Narin 1976: 1).

Illk olarak 1922'de "istatistiksel bibliyografya" adıyla anılan bu yöntemin isim babası olarak E. Wyndham Hulme gösterilmektedir (Pritchard 1969: 348). Ancak istatistiksel bibliyografya teriminin yıllar boyunca birkaç istisna dışında kabul görüp kullanılmadığını belirten Pritchard (1969: 348-349), onun yerine "bibliyometri" terimini önerir. Pritchard (1969: 349) bibliyometriyi, matematiksel ve istatistiksel yöntemlerin kitap ve diğer iletişim araçlarına uygulanması olarak tanımlar. Bu yöntem akademik iletişimin yapısını ve işleyişini araştırmak için güçlü araçlar sunmaktadır (Borgman ve Furner 2002: 2). Artık kabul görmüş bir araç olarak bibliyometri, sayısal yöntemlere dayanan bilim dallarında daha yoğun biçimde kullanılmakla birlikte çok çeşitli kullanım alanlarına sahiptir (Borgman ve Furner 2002: 3). Bibliyometrik yöntem genel olarak akademik iletişimi tanımlama, açıklama, değerlendirme ve tahmin etmede işlev görmektedir (Borgman ve Furner 2002: 5). 
Belli bir dalda yapılan çalışmalar zaman içinde birikir ve literatürü oluşturur. Bir disiplindeki akademisyenlerin, o disiplinde yapılan araştırmaların eğilimlerini, genel karakteristiğini tespit edebilmesi önemlidir. Her disiplinin araştırma eğilimleri gerek disiplin içi gerekse dışı nedenlerle değişiklikler gösterir. Bu, o bilim dalının araştırmacıları tarafından gözlenebilen bir olgudur. Bibliyometrik bir çözümleme ise literatür birikiminin tümünü ya da belli bir kesitini ele alarak, ilgili disiplinin zaman ve mekandaki devinimiyle ilgili somut veriler sunar, genellemeler yapar. Öznel gözlemleri denemeye ve nesnelleştirmeye olanak sağlar. Bunun yanında, araştırmacıların etkilenme kaynaklarını ortaya koyar. Bir bilim dalının gelecekteki muhtemel yönelimine dair çıkarımlarda bulunmaya yardımcı olur. Araştırmacılara ise araştırma konuları belirlemede ve kariyer planlama açısından veri sağlayabilir.

Bibliyometri, bir disiplindeki yıllara göre araştırma eğilimlerini, ele alınan konuların ve kullanılan yöntemlerin çeşitliliğini değerlendirmede kullanılabilecek etkili bir araç olarak önem kazanmaktadır. Iletişim, halkla ilişkiler ve reklam alanlarında yerli ve yabancı bibliyometrik incelemelerin mevcut olduğu görülse de sinema araştırmaları söz konusu olduğunda Türkçe ve İngilizce literatürde yeterli çalışma gözlenmemiştir.

Enformasyon bilimi ve iletişim alanında Borgman ve Rice (1992)'ın çalışmaları, halkla ilişkiler alanında Pasadeos (1985), Üsdiken ve Pasadeos (1995), Feeley (2008), Reeves ve Borgman (1983)'ın çalışmaları bu alandaki yapılan araştırmalara örnek gösterilebilir. Pasadeos vd. (2010) halkla ilişkiler literatüründe hangi tür kaynakların kullanıldığını, en fazla atıf yapılan kaynakları, en aktif yazarları tespit etmişler, önceki dönemlerle karşılaştırmalar yapmışlardır. Benzer bir çalışma (Pasadeos 1985) reklamcılık alanında yapılmış, ABD'de yayınlanmış bir grup reklamcılık makalesindeki atıflar analiz edilerek, literatür yaşlanma hızı, reklam literatürünün beslenme kaynakları analiz edilmeye çalışımıştır. Çalışmanın ilgi çekici boyutlarından biri, reklamcılık literatürünün iletişim yerine büyük oranda işletme ve psikoloji disiplinlerinden beslendiği, iletişim literatürünün kaynak olarak yalnızca yaklaşık \% 5 oranında makalelerde yer bulduğu tespitidir (Pasadeos 1985: 57).

Bibliyometrik çalışmalar, Ross (2010), Yalçın (2010), Coronado vd. (2011)'nin bir akademik dergide yayın yapan yazarların menşei, çalışııları kurumlar, yazar üretkenliği, atıfta bulundukları kaynaklar vb. özellikleri üzerine gerçekleştirdiği analizler türünden, bir akademik derginin yıllar içindeki profilini ortaya koyabilecek özellikte olabileceği gibi belli bir alandaki bir grup akademik yayın üzerine de gerçekleştirilebilir. Örneğin Feeley (2008), yapmış olduğu çalışmada, 2002-2005 yılları arası yayınlanmış iletişim dergilerini ele almıştır. Reeves ve Borgman (1983) ise yaptıkları iletişim dergileri analizinde iletişim araştırmacılarının diğer disiplinlerden etkilenme oranlarını ölçmeye çalışmışlardır.

Türkiye'de tezler üzerine yapılan analizlerin içerik çözümlemesi ve atıf analizi şeklinde nitelendirilebilecek iki ana türde olduğu; içerik çözümlemelerinde 
genelde yöntem ve konuların, atıf analizinde ise atıf yapılan kaynakların incelendiği bilinmektedir (Uçak ve Al, 2009: 167). Birinci türdeki çalışmalara örnek olarak Okay ve Okay (2008a; 2008b) ile Yılmaz ve Uzoğlu (2003)'nun halkla ilişkiler alanında tamamlanmış lisansüstü tezleri inceledikleri çalışmaları gösterilebilir. Okay ve Okay (2008b: 313)'ın çalışmalarında 1984-2007 yılları arasında tamamlanmış halkla ilişkiler lisansüstü tezleri incelenmiş; analiz sonuçlarından biri olarak tezlerin çoğunluğunun uygulamalı halkla ilişkiler alanında yazıldığı, diğer yandan teorik çalışmaların tamamen inmal edildiği tespit edilmiştir. Yılmaz ve Uzoğlu (2003) ise 1992-2001 yılları arasında tamamlanmış lisansüstü tezleri konularına göre inceleyerek halkla ilişkiler ve reklamcılık alanındaki araştırma eğilimlerini, en çok ve en az çalışılan tez konularını değerlendirmişlerdir.

Diğer yandan Uçak ve Al (2009), Hacettepe Üniversite'nde 1968-2007 yılları arasında 16 farkı disiplinde hazırlanmış olan yüksek lisans ve doktora tezlerinde kullanılan kaynakları çözümleyerek bibliyometrik analizin başka bir türü olan atıf analizi çalışması gerçekleştirmişlerdir. Hangi kaynakların ne sıklıkta kullanıldığından yola çıkarak bilim dallarındaki literatür yaşlanma hızını, doktora ve yüksek lisans tezleri arasında kaynak kullanımı açısından farklıık olup olmadığını, bilim dallarına göre atıf çeşitliliğini incelemişlerdir.

Atıf analizleri yoluyla araştırmalarda hangi yayınların kaynak olarak kullanıldığı karşılaştırmalı olarak ortaya konurken, etkili yazarlar ve yayınlar ortaya çıkarılarak akademisyenlerin etkilenme kaynakları tespit edilebilmektedir. Ayrıca görüldüğü üzere bibliyometrik yöntemle, tek bir disiplinin seyrini belgelemek yanında farklı bilim dallarını belli özellikler çerçevesinde karşılaştırmak, benzerlik ve farklılıkları tespit etmek de mümkündür. Bu tür analizler, ülkelerin uluslararası bilimsel üretimdeki yerlerinin tespitine ve yükseköğretim kurumlarının bilimsel politikalarının planlanmasına da yarayabilecek veriler üretebilmektedir.

Sinema araştırmalarında bir süredir birikmekte olan literatürün çeşitli niteliklerine dair veriler toplayarak analiz etmek sinema araştırmalarıyla ilgilenenlere alanın özelliklerini ve yönelimlerini daha somut bir biçimde tanıma olanağı sağlayacaktır. Elde edilen bulgular ayrıca, ulusal ve uluslararası ölçekteki diğer sinema literatürü ile karşılaştırmalar yapmaya da olanak tanıyabilecektir.

Bu çalışmada hem bu güne kadar yapılan lisansüstü sinema araştırmalarının bu disiplin açısından genel karakteristiğini ortaya koymak, hem de gelecekteki araştırmalara bir kaynak olması amacıyla, Türkiye'de 1985 yılından itibaren üretilen ve sinemayı konu alan doktora/sanatta yeterlilik ${ }^{1}$ tez çalışmaları içeriğe dair belirli özellikleri açısından çözümlemeye tabi tutulmuştur.

1 Buradan sonra hem doktora hem sanatta yeterlilik tezlerini kapsayıcı şekilde "doktora" terimi kullanılacaktır. 


\section{Yöntem ve Sınırıılıklar}

Araştırmada 1985-2013 yılları arasında Türkiye'de sinema üzerine tamamlanmış 199 doktora tezi incelenmiştir. Tezler bibliyometrik özellikleri açısından analiz edilmiştir. Bibliyometrik bir çalışmada yukarıda da belirtildiği üzere çok farklı düzeylerde çözümlemeler yapmak mümkündür. Burada yapılmış olan analizde Türkiye'de sinema konusunda hazırlanmış doktora düzeyindeki tezler, yıllara göre dağıımları, üniversitelerde hangi anabilim veya anasanat dalı altında üretildikleri, sinema disiplini açısından hangi temel araştırma alanı içinde yer aldıkları, yaslandıkları eleştirel yaklaşımlar ve kuramlar, sinemanın hangi yapım türlerini araştırma konusu edindikleri, hangi coğrafi bölgelerin sinemasını kapsadıkları, yazılmış oldukları diller ve içerdikleri anahtar kelimeler çerçevesinde çözümlenmişlerdir.

Incelemeye alınan tezlere Yüksek Öğretim Kurulu'na bağlı Ulusal Tez Merkezi internet veri tabanı üzerinden erişilmiştir. Yapılan bir dizi tarama sonucunda tespit edilen doktora düzeyindeki 199 araştırma sinema tezi olarak nitelendirilmiştir. Bu tezler incelenerek yukarıda sıralanan özelliklere dair elde edilen bulgular analiz edilmiștir. Çalışmada YÖK Ulusal Tez Merkezi'nin https://tez. yok.gov.tr internet adresinden ulaşılan kayıtlarında 10 Haziran 2013-17.01.2014 tarihleri arasında yapılan taramaların sonuçları esas alınmıştır.

Sınırlııklara dair belirtilmesi gereken bir başka nokta sanatta yeterlilik tezleri arasında yer alan görsel-işitsel çalışmalar ve bunlara dayanan raporların araştırma kapsamı dışında tutularak yalnızca yazıı tez araştırmalarının çalışmaya dâhil edilmiş olduğudur. Ayrıca, taramalar sonucunda ulaşılan ve içerikleri incelenen tezlerden başka konular yanında sinemaya da değinen, ancak doğrudan sinemayı inceleme konusu yapmayan çalışmalar da araştırma kapsamı dışında tutulmuştur. Buna karşın disiplinler arası bir yaklaşımla sinema ve diğer bir sanat dalını veya akademik alanı ele alan -örneğin uyarlamaları inceleyen- karşılaştırmalı çalışmalar, ait oldukları anabilim dalları ya da konu kategorilerine bakılmaksızın araștırma kapsamına dâhil edilmişlerdir. Bu nedenle, çalışma yalnızca Türkiye'de İletişim ve Güzel Sanatlar Fakülteleri altında örgütlenmiş, sinema eğitimi veren, sinema araştırması yapan bölümlerle ilişkili lisansüstü üretimlerini değil; farklı disiplinlere bağlı çok çeşitli doktora ya da sanatta yeterlik programlarında yapılımış araştırmaları da kapsamaktadır.

Araştırma evreninin mümkün olduğunca tamamının temsili ile doğruluk payının artması ve daha anlamlı sonuçlar elde edilmesi amacıyla çeşitli şekillerde veri tabanı taraması yapılmıştır. Yalnızca tez başlıklarının taranması tatmin edici sonuçlar vermemektedir. Ayrıca, Ulusal Tez Merkezi'nin veri tabanının konulara göre tezler listesinde2 "sinema" konusu mevcut değildir. Radyo-Televizyon, Illetişim Bilimleri, Sahne ve Gösteri Sanatları en yakın konular olarak göze çarpmaktadır. Sinema tezlerinin çoğunluğu bu konular altında kayıtlıdır.

2 https://tez.yok.gov.tr/UlusalTezMerkezi/lstatistikiBilgiler?islem=3 
Veri tabanı taraması iki aşamada gerçekleştirilmiştir: IIlk aşamada, başlı̆ında ya da öz kısmında "sinema" sözcügü içeren doktora ve sanatta yeterlilik tezleri ayrı ayrı taranmıştır. Ancak bazılarının öz kısmı eksik olduğundan başka taramalar da yapılmış; dizin kısmında "sinema" sözcügü içeren doktora ve sanatta yeterlik tezleri de taranmıştır. Bu ilk taramalarda 186 adet doktora ve eşdeğeri düzeyde teze ulaşıımıştır. Ardından, başığı "sinema" sözcüğü içeren tezler ile ilk aşamada tespit edilmiş olan tezlerin yarısından fazlasını içeren "Radyo, Televizyon ve Sinema", "Sinema Televizyon", "Iletişim Bilimleri" anabilim dalları ile "Sinema Televizyon" anasanat dallarında hazırlanmış tüm tezlerin öz kısımlarında "film" sözcügü aranmıştır ${ }^{3}$. Böylece 13 adet doktora ve eşdeğeri düzeyde tez daha tespit edilerek bu sayı 199' a ulaşmıştır.

Yükseköğretim Kurulu Başkanlığı'nın (2010) tez veri tabanı ile ilgili olarak, "Tezlerin, eksiksiz olarak teslim alınması, YÖK Ulusal Tez Merkezi Veri Tabanına yüklenmesi ve Tez Veri Girişi ve Yayımlama İzin Formunun gönderilmesi enstitülerin sorumluluğundadır." talimatına karşın, bir kısım tezin öz, anahtar kelimeler, anabilim dalı ve konu bilgilerinde eksikler bulunduğu görülmüştür. Örneğin, YÖK ulusal tez merkezi veri tabanında doktora tezlerinin \%19,09' unun (38 adet) anabilim dalları belirtilmemiştir. Bulundukları kütüphane kayıtlarından veya tam metin olarak erişilen bu tezler incelenerek anabilim dalları bilgileri eklenmiştir. Son yıllardaki kayıtlar daha düzenli ve eksiksiz olmakla birlikte özellikle veri tabanının eski tarihli tez kayıtlarının daha fazla veri eksiği mevcuttur. Bu nedenle, araştırma kapsamında gereken ancak, katalog kayıtlarında eksik olan veriler için tezler, To-Kat ${ }^{4}$ (Toplu Katalog) ve üretildikleri üniversitelerin kütüphane kataloglarında çapraz sorgulamalarla yeniden taranarak eksik veriler önemli ölçüde tamamlanmıştır. Yine de belirtmek gerekir ki bazı tezlerin üniversite katalog kayıtlarında da eksik ve hatalar mevcuttur. Örneğin, Yüksek Lisans-Doktora ayrımının bazı üniversitelerin veri tabanlarında belirtilmediği, nadiren de olsa kitapların tez, tezlerin kitap olarak kaydedildiği, Ulusal Tez Merkezi kayıtlarında mevcut olan kimi bilgilerin yer almadığı görülmektedir.

\section{Bulgular}

Türkiye'de 1985-2013 yılları arasında sinema ile ilgili toplam 199 doktora ve sanatta yeterlik düzeyinde tez çalışması yapılmıştır. ${ }^{5}$ Yıldan yıla değişmekle birlikte söz konusu 29 yıllık dönem boyunca yılda ortalama 6,86 sinema tezi tamamlanmıştır. En fazla tez üretilen yıl 2012 (22) ve 2013 (22) iken 1985, 1986, 1988, 1991 ve 2000 yıllarında yalnızca birer tez tamamlanmıştır. 1987 yılında ise sinema konusunda tamamlanmış bir araştırmaya rastlanmamıştır.

3 "Film" sözcüğü fen ve mühendislik bilimlerinde de kullanılan bir terim olduğundan dolayı burada tarama sınırlandırılmıştır.

4 http://www.toplukatalog.gov.tr/

5 17.01.2014 itibarı ile YÖK Ulusal Tez Merkezi veri kayıtlarına göre. 
Zaman içinde doktora araştırma sayısında bir artış olduğu gözlenmiş olup 2012 ve 2013 yıllarında en yüksek seviyesine ulaşmıştır. 2000'lere kadar benzer düzeylerde seyreden tez sayısı, 2000'li yıllarla birlikte belirgin bir biçimde artmış; özellikle 2008 yıından itibaren tez çalışmalarının sayısının çift haneli rakamlara ulaşmış olduğu gözlenmiştir (Grafik 1). Doktora araştırmalarının \%78,89'u 2000 yılından sonra yapılmıştır. Bunun \%50,25'lik kısmı (100) 2008-2013 yılları arasında gerçekleştirilmiştir. Dönemsel bir karşılaştırma yapıldığında, 1980'lerde yılda ortalama 1,4 tez yazilırken 1990'larda 3,4,2000'lerde 8,7 ve 2010'lu yıllarda şu ana kadar yılda ortalama 17,75 doktora tezi yazılmış olduğu görülmektedir.

Grafik 1: Yıllara Göre Doktora Tez Sayıları (n=199)

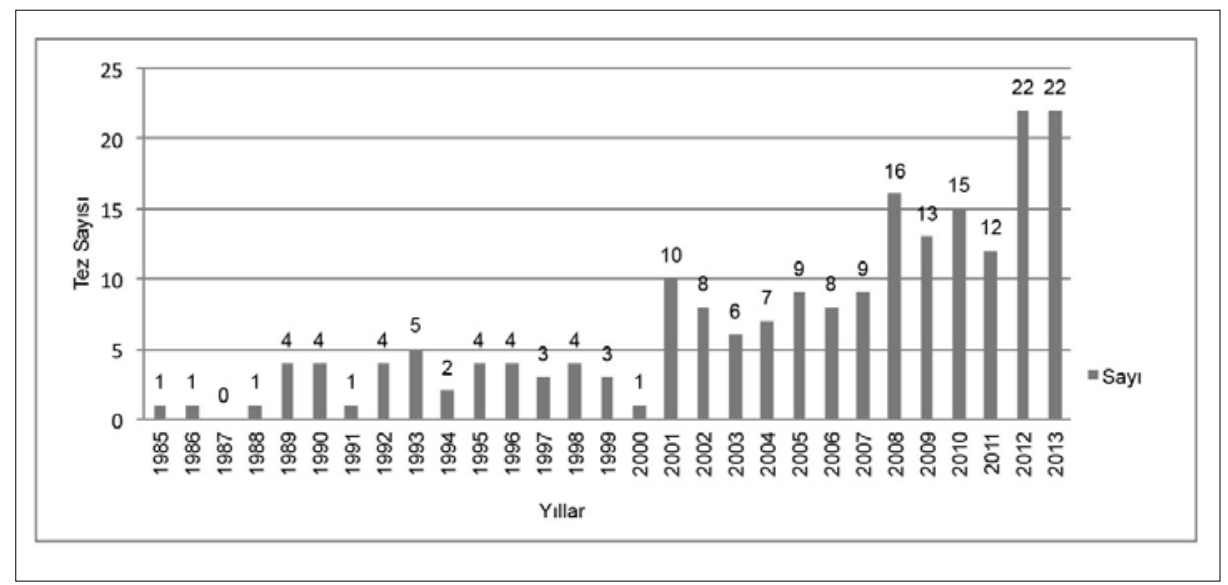

Bu çalışmada belli başlı sinemasal yapım türleri olarak kurmaca, belgesel, deneysel ve canlandırma kabul edilmiştir. Doktora tez araştırmalarının üzerine yoğunlaşmış oldukları bu yapım türleri ele alındığında, en fazla sayıda (173) tezin $(\% 86,93)$ kurmaca yapımlar üzerine üretildiği tespit edilmiştir (Tablo 1). Belgeselin payı, 11 tez ile \%5,53 iken deneysel filmler ve canlandırma sineması üzerine ise yaklaşık 30 yıllık süre içinde yalnızca 2'şer doktora araştırması $(\% 2,02)$ ortaya konmuştur. Doktora araştırmasının konusu, yukarıda anılan yapım türlerinden bağımsız olarak sinema alanının genelini kapsayıcı nitelikte olan çalışmalar ise 11 tez ile \%5,53 oranında temsil edilmiştir. Belgesel, deneysel ve canlandırma filmlerini konu alan tez çalışmalarının (15) çoğunluğunun son yıllarda gerçekleştirilmiş olması dikkat çekicidir (Grafik 2). 
Tablo 1: Tezlerde Ele Alınan Yapım Türleri

\begin{tabular}{|l|l|l|}
\hline Film Yapım Türleri & $\mathbf{n}$ & $\%$ \\
\hline Kurmaca & 173 & 86,93 \\
\hline Belgesel & 11 & 5,53 \\
\hline Canlandırma & 2 & 1,01 \\
\hline Deneysel & 2 & 1,01 \\
\hline Diğer & 1 & 5,53 \\
\hline $\begin{array}{l}\text { Belirli bir yapım türüne } \\
\text { odaklanmayan }\end{array}$ & 11 & 86,93 \\
\hline Toplam & 199 & 100 \\
\hline
\end{tabular}

Grafik 2: Yapım Türlerinin Yıllara Göre Dağıımı

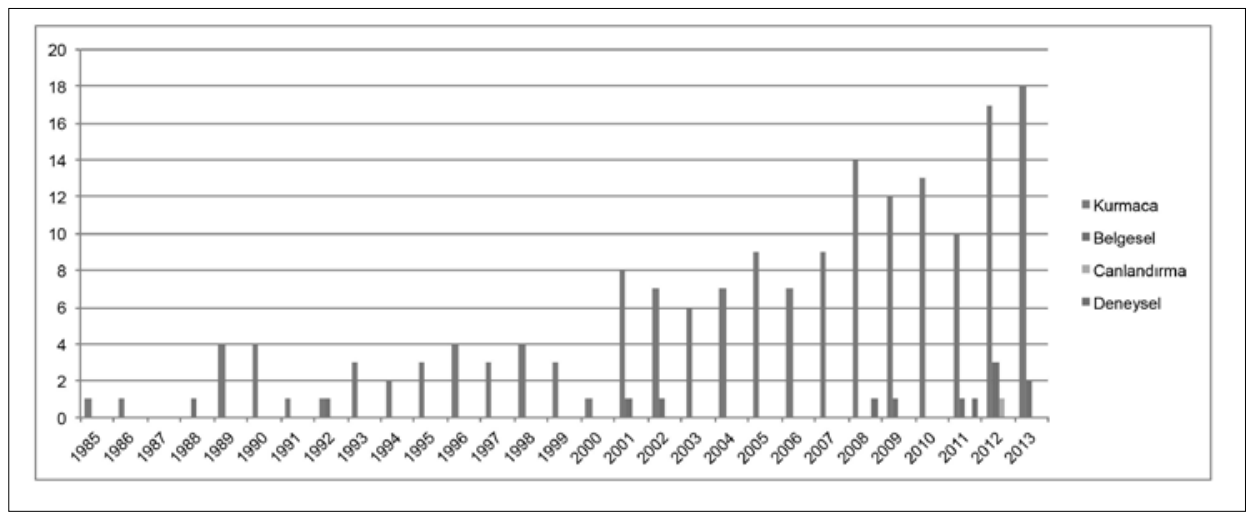

Bir başka inceleme konusu da sinema araştırmalarının odaklandığı alanlardır. Sinema araştırmalarında, sinema disiplinindeki genel kanıya göre, kuram, eleştiri ve tarih olmak üzere üç temel araştırma alanında faaliyet gösterilir (Elsaesser ve Buckland 2002:2). Bu üç temel araştırma alanı doktora düzeyindeki üretimin dağıımını tespit etmek amacıyla kategoriler olarak çalışmaya katıldı. Araştırmada ayrıca, bu üç kategori dışında kalan yapım, dağıtım, gösterim, teknoloji, arşivcilik, hukuk vb. çeşitli konuları ele alan çalışmalar için ayrı bir kategori oluşturulmuştur.

Buna göre, doktora araştırmalarının \%56,31'i (116) eleştirel çalışmalardır (Tablo 2). Buna karşın \%16,76'sının (34) kuramsal, \%12,62'sinin (26) sinema tarihi çalışması olduğu tespit edilmiştir. Yapım, dağıtım, teknoloji, hukuk, vb. de $\% 14,56$ oranında (30) tezlerde araştırma konusu olmuştur. Araştırmaların bazıları birden fazla gruba dâhil edilebilecek tezlerdir. Örneğin, yapımcılık tarihi ile ilgili bir çalışma hem yapım hem sinema tarihi kategorisinde yer alabilmektedir. 
Tablo 2: Tezlerde Beliren Temel Araştırma Alanları

\begin{tabular}{|l|l|l|}
\hline Temel Alan & $\mathbf{n}$ & $\mathbf{\%}$ \\
\hline Eleştiri & 116 & 56,31 \\
\hline Kuram & 34 & 16,50 \\
\hline Tarih & 26 & 12,62 \\
\hline Yap. - Dağ. - Gös. - Tek. & 30 & 14,56 \\
\hline Toplam & 206 & 100 \\
\hline
\end{tabular}

Kültürel bir ürün olarak filmlerin hangi ülke yapımı olduğu bilgisi önemli bir bibliyografik veridir. Incelenen 199 tez, içerikleri çerçevesinde çeşitli ülkelerin sinematografik üretimlerini ele almışlardır. Bu çalışmada coğrafi genelleme yapılarak ülke sinemaları, Türkiye dışındaki ülkeler için Avrupa, Asya, Afrika, Avustralya, Kuzey ve Güney Amerika olarak kategorilere ayrılmıştır. Araştırmaların yöneldiği coğrafya açısından yapılan analizde doktora çalışmalarının yarıdan fazlasının (117 tez ve \%56,25) yerli sinema üzerine gerçekleştirilmiş olduğu belirlenmiştir (Tablo 3). Ardından \% 10,58 (22) ile Kuzey Amerika (ABD - Hollywood) sineması gelirken; Avrupa sineması ile ilgili çalışmalar \%9,62 (20), Asya sineması ise \%2,40 (5) oranında tezler arasında yer almıştır. Afrika, Avustralya ve Latin Amerika ülkeleri sinemaları üzerine ise herhangi bir araştırmaya rastlanmamıştır. Araştırmaların \%21,15'i (44) ise özel olarak herhangi bir ülke ya da bölgenin sinematografik üretimiyle sınırlandırılmamış, genellikle kuramsal ya da teknik konulara değinen çalışmalardır. Ayrıca belirtmek gerekir ki araştırmalardan \%4,52'si (9) birden fazla coğrafyayı kapsayıcı karşılaştırmalı çalışmalardır.

Tablo 3: Tezlerde Araştırılan Ülke Sinemaları

\begin{tabular}{|l|l|l|}
\hline Bölge & $\mathbf{n}$ & $\mathbf{\%}$ \\
\hline Türkiye & 117 & 56,25 \\
\hline Kuzey Amerika & 22 & 10,58 \\
\hline Avrupa & 20 & 9,62 \\
\hline Asya & 5 & 2,40 \\
\hline Afrika & 0 & 0 \\
\hline Latin Amerika & 0 & 0 \\
\hline Avustralya & 0 & 0 \\
\hline Belirsiz & 44 & 21,15 \\
\hline Toplam & 208 & 100 \\
\hline
\end{tabular}


1985-2001 yılları arasında bazı yıllar6 Türk sinemasının hiç ele alınmamış olduğu, diğer yıllarda da Türkiye ve dünya sinemalarının birbirine daha yakın oranlarda araştırma konusu olarak seçilmiş olduğu görülmektedir (Grafik 2). Bu yıllar arasında yapılan araştırmalarda Türkiye ve diğer ülke sinemalarının ele alıış sayısı 22'ye 14'tür. 2002 yılından itibaren ise doktora çalışmalarının toplam sayısında dramatik bir artış olmakla birlikte, Türk sineması üzerine yapılan çalışmaların artış oranının diğer ülke sinemaları üzerine yapılan çalışmaların artış oranına göre dikkate değer bir biçimde yüksek olduğu tespit edilmiştir. Bu tarihten sonra yerli sinemanın doktora tezlerinde ele alınma sıklığı (92) diğer ülke sinemalarınınkinin yaklaşık üç katına (32) ulaşmıştır.

\section{Grafik 3: Yıllara Göre Türk ve Dünya Sineması Üzerine Yazılan Doktora Tezleri}

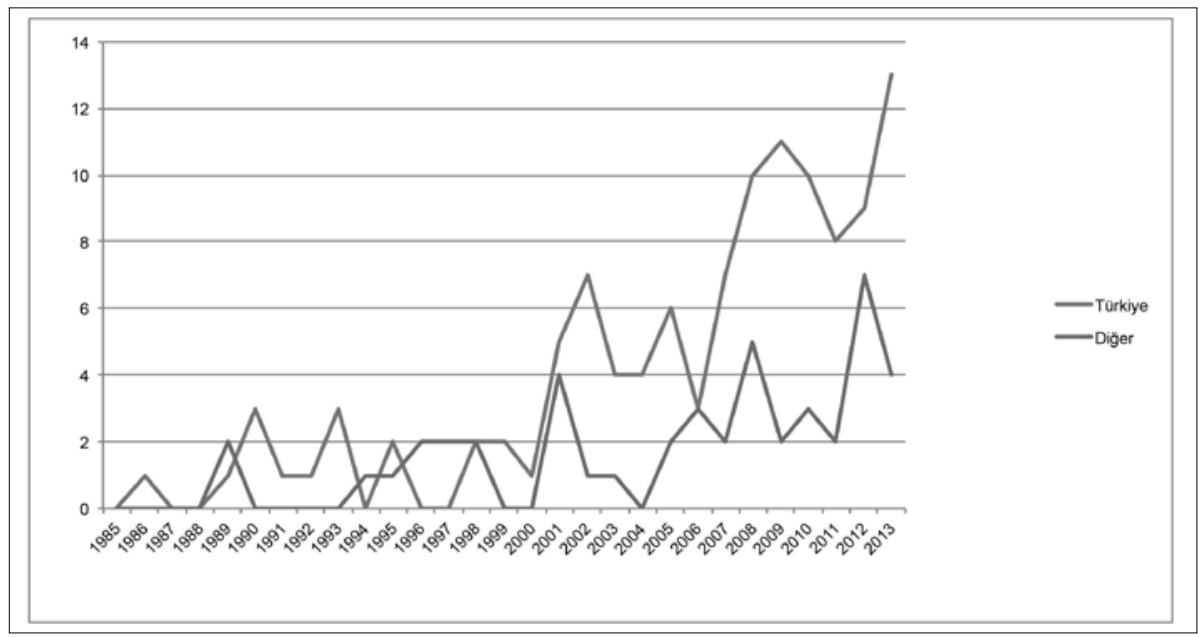

Sinema alanının disiplinler arası niteliğini kanıtlar nitelikte, 1985-2013 yılları arasında, üniversitelerdeki 37 farklı anabilim/anasanat dalında sinema üzerine tez yazılmış olduğu tespit edilmiştir (Tablo 4). 29 yıllık süre içinde bünyesinde onun üzerinde tez üretilen anabilim ve anasanat dalları altı tanedir. Bunların hepsi sinema eğitimi veren İletişim ve Güzel Sanatlar Fakülteleri bağlantılı enstitü anabilim dallarıdır ve isimleri Radyo, Televizyon ve Sinema ABD (57), Sinema (ve) Televizyon ABD (23), Sinema Televizyon ASD (22), İletişim Bilimleri ABD (21), Sahne ve Görüntü Sanatları ABD (13), Radyo Televizyon ABD (13)'dır. Bu altı anabilim/anasanat dalının doktora araştırmalarındaki payı \% 74,87 (149)'dir. Bu gruba sinema eğitimi veren fakülte/bölüm bağlantıı diğer anabilim dalları (illetişim, Sinema, Sahne ve Görüntü Sanatları ASD, Gazetecilik) da eklendiğinde bu oran $\% 76,88$ 'e ulaşmaktadır. Geriye kalan 46 tez ise diğer akademik disiplinlerin anabilim/anasanat dalları altında yürütülmüş olan araştırmalardır ve toplamın

$61985,1988,1994,1996,1997$. 
\%23,12'sini oluşturmaktadır. Bu grubun üst sıralarında toplamda üç ve üstü tez sayılarıyla Grafik, Fransız Dili ve Edebiyatı, Amerikan Kültürü ve Edebiyatı, Mimarlık ve Sosyoloji (toplam 18 tez, \%9,05) disiplinleri yer almaktadır. Bunlar, sinema disiplinine yaklaşan, onunla alışveriş içine giren alanlar olarak nitelendirilebilirler. Geriye kalan anabilim/anasanat dallarında üretilen tezlerin katkısı ise araştırılan zaman diliminde, çoğunluğu birer tezden oluşmak üzere toplamda 22 farklı dal altında toplanmıştır (28 tez; \% 14,07).

Tablo 4: Anabilim/Anasanat Dallarına Göre Tezlerin Dağııımı

\begin{tabular}{|l|l|l|}
\hline Anabilim/Anasanat Dalı & $\mathbf{n}$ & $\%$ \\
\hline Radyo, Televizyon ve Sinema & 57 & 28,64 \\
\hline Sinema Televizyon (ABD) & 23 & 11,56 \\
\hline İletişim Bilimleri & 21 & 10,55 \\
\hline Sinema Televizyon (ASD) & 22 & 11,06 \\
\hline Sahne ve Gör. Sanatları (ABD) & 13 & 6,53 \\
\hline Radyo Televizyon & 13 & 6,53 \\
\hline Grafik & 4 & 2,01 \\
\hline Fransız Dili ve Edebiyatı & 3 & 1,51 \\
\hline Amerikan Kültürü ve Edebiyatı & 4 & 2,01 \\
\hline Mimarlık & 4 & 2,01 \\
\hline Sosyoloji & 3 & 1,51 \\
\hline Felsefe ve Din Bilimleri & 2 & 1,01 \\
\hline Antropoloji & 2 & 1,01 \\
\hline Sanat ve Tasarım & 2 & 1,01 \\
\hline Yabancı Diller Eğitimi & 2 & 1,01 \\
\hline Alman Dili Eğitimi & 2 & 1,01 \\
\hline Batı Dilleri ve Edebiyatı & 2 & 1,01 \\
\hline İletişim & 1 & 0,50 \\
\hline Sinema & 1 & 0,50 \\
\hline Sahne ve Gör. Sanatları (ASD) & 1 & 0,50 \\
\hline Gazetecilik & 1 & 0,50 \\
\hline Felsefe & 1 & 0,50 \\
\hline Felsefe Tarihi & 1 & 0,50 \\
\hline
\end{tabular}




\begin{tabular}{|l|l|l|}
\hline İşletme & 1 & 0,50 \\
\hline Sanat Tarihi & 1 & 0,50 \\
\hline Hukuk & 1 & 0,50 \\
\hline Yeni Türk Edebiyatı & 1 & 0,50 \\
\hline İlahiyat & 1 & 0,50 \\
\hline Temel İslam Bilimleri & 1 & 0,50 \\
\hline Avrupa Topluluğu & 1 & 0,50 \\
\hline İngiliz Dili ve Edebiyatı & 1 & 0,50 \\
\hline Siyaset Bilimi ve Uluslararası Ilişkiler & 1 & 0,50 \\
\hline Eğitim Programları ve Öğretim & 1 & 0,50 \\
\hline Eğitim Bilimleri & 1 & 0,50 \\
\hline Türk Edebiyatı & 1 & 0,50 \\
\hline Sahne Sanatları & 1 & 0,50 \\
\hline Sahne ve Kostüm Sanatları & 1 & 0,50 \\
\hline Toplam & 199 & 100 \\
\hline
\end{tabular}

Türkiye'de hem geleneksel olarak IIletişim ve Güzel Sanatlar Fakülteleri altında konumlanmış bölümlerde sürdürülen eğitim ve araştırma faaliyetleriyle bağlantılı bir biçimde yürüyen lisansüstü anabilim/anasanat dallarında sonuçlanan tezlerin hem de diğer anabilim/anasanat dallarında tamamlanmış sinema tezlerinin sayısının giderek arttığı gözlenmektedir (Grafik 3). 1990'ı yılların ortalarından önce farklı anabilim dallarında sinema çalışması ortaya çıkmamıştır. Alan dışı olarak nitelendirilebilecek ilk tezin 1994 yılında Ingiliz Dili ve Edebiyatı ABD'ında hazırlandığı görülmüştür. Toplam tez üretimindeki artışa paralel olarak 2001'den itibaren alan dışından tez sayısı da önemli ölçüde artmıştır. Bu gruptaki 39 tezin yalnızca 5'i 1990'lı yıllarda üretilmişken 34'ü 2000'li ve 2010'lu yıllarda tamamlanmıştır. Bu tezler de doktora araştırma sayısına önemli bir katkı sağlamaktadır.

Diğer bir deyişle başlangıcından 2001 yıına kadar üretilen tezlerin yalnızca \%12,19'u alan dışından, \% 88, 81'i alan içinden iken; söz konusu artışın görüldüğü 2001 ve sonrasında tamamlanmış doktora tezlerinin \% 75,36'sı (104) alan içinden olarak tespit edilmiş olup, alan dışı olarak nitelendirebileceğimiz tezlerin oranı \%24, 64'e (34) ulaşmıştır. Denilebilir ki, alan içi doktora araştırma sayısı önemli miktarda artmış olmakla birlikte bu artış oranı alan dışındaki tezler içinde daha fazla olmuştur. Alan dışı tezler oransal olarak yaklaşık onda birden dörtte bir seviyesine ulaşmıştır. 
Grafik 4: Alan Içi ve Dışı Tez Sayılarının Yıllara Göre Değişimi

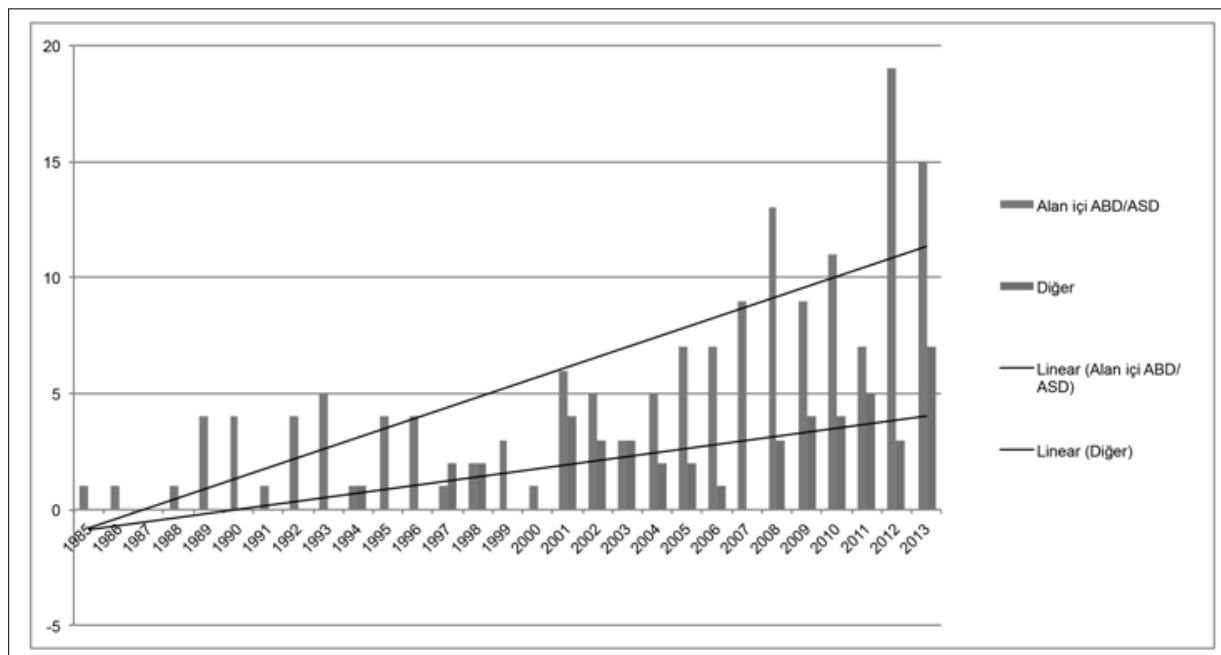

Sinema araştırmaları disiplinler arası niteliği nedeniyle çok çeşitli yöntemsel, kuramsal yaklaşımları içerebilmektedir. Bu çalışmada, biçim ve biçem incelemeleri, auteur, göstergebilimsel, psikanalitik, feminist, ideolojik, tarihsel, toplumbilimsel, felsefi, bilişsel yaklaşımlar, yıldız ve izleyici, postmodernizm, tür eleştirisi ve ulusal sinema olmak üzere sinema araştırmalarında dünden bugüne rol oynamış olduğu bilinen belli eleştirel yaklaşım, yöntem ve kuramlar çerçevesinde bir sınıflandırılma yapılmıştır. 199 tezde toplam 225 yöntem ve yaklaşım belirmiştir (Tablo 5 ve Tablo 6). Araştırmalarda en fazla yararlanılan yöntem toplumbilimsel yaklaşım olmuştur. Toplumbilimsel bakış açısı, ele alınan dönem içinde yapılan araştırmaların yaklaşık beşte birinde $(\% 19,82)$ (44 tez) görülmektedir. Başlangıcından günümüze sinema araştırmalarının çekirdeğini oluşturan, sinemanın anlatı yapısı, mizansen, sinematografi, kurgu ve ses boyutu gibi biçim ve biçem sorunlarına odaklanan çalışmalar ise ikinci sırada yer almaktadır (37 tez; \%16,67).

Üçüncü sıradaki en fazla tercih gören araştırma yöntemi ise ideolojik çözümleme yaklaşımıdır (27 tez; \% 12,16). Tarihsel yaklaşım \%9,91 (22 tez); tür eleştirisi 16 çalışmayla \%7,21; feminist yaklaşım ve toplumsal cinsiyet odaklı çalışmalar \% 7,21 (16) olarak belirlenmiştir. Göstergebilimsel, psikanalitik, auteur, yıldız, 3. Sinema, ulusal sinema, postmodernizm ve bilişsel yaklaşımlar daha az yer bulmuştur. Doktora tezlerinin \%6,76'sı (15) burada adı geçmeyen çok sayıda farklı yöntem ve yaklaşımı içerirken; \%10,36'sında (23) ise herhangi belirgin bir yaklaşımın varlığı tespit edilememiştir. 
Tablo 5: Tezlerde Kullanılan Yöntem ve Yaklaşımlar

\begin{tabular}{|l|l|l|}
\hline Yöntem ve/veya Yaklaşımlar & $\mathbf{n}$ & $\%$ \\
\hline Toplumbilimsel & 44 & 19,56 \\
\hline Biçim ve Biçem & 37 & 16,44 \\
\hline Ideolojik & 27 & 12,00 \\
\hline Tarihsel & 22 & 9,78 \\
\hline Tür Eleştirisi & 16 & 7,11 \\
\hline Feminizm ve Toplumsal Cinsiyet & 16 & 7,11 \\
\hline İleyici & 12 & 5,33 \\
\hline Göstergebilimsel & 8 & 3,56 \\
\hline Felsefe & 7 & 3,11 \\
\hline Psikanalitik & 7 & 3,11 \\
\hline Auteur & 5 & 2,22 \\
\hline 3.Sinema/Ulusal Sinema & 4 & 1,78 \\
\hline Postmodernizm & 2 & 0,89 \\
\hline Bilişsel & 2 & 0,89 \\
\hline Yıldız & 1 & 0,44 \\
\hline Diğer & 15 & 6,67 \\
\hline Toplam & 225 & 100 \\
\hline
\end{tabular}


Tablo 6: Yöntem ve Yaklaşımların Yıllara Göre Dağılımı

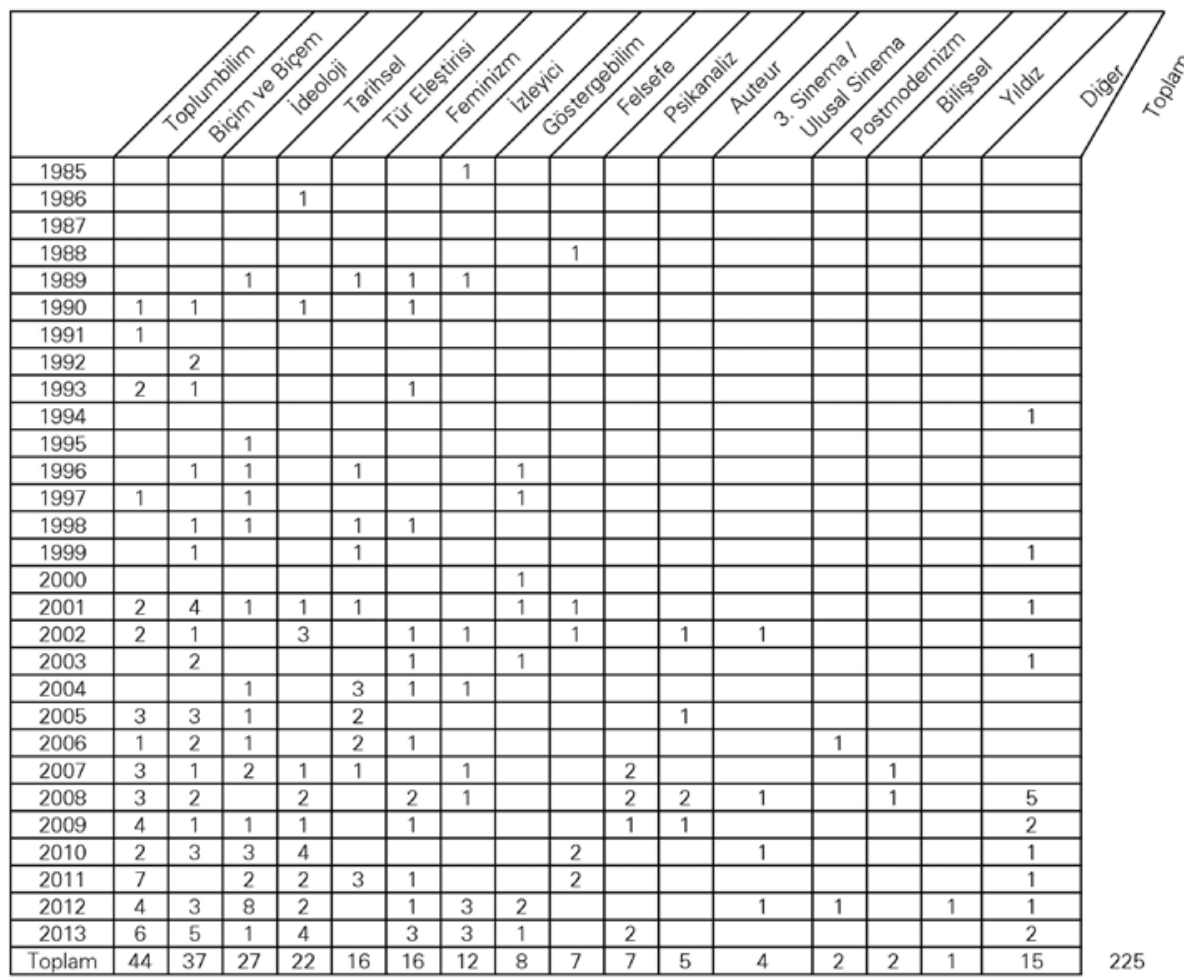

Tez yazarlarının kendi çalışmaları için belirlemiş oldukları anahtar kelimeler ele alındığında, araştırmacılar tarafından en sık kullanılan ve diğerlerine göre sayıca büyük farkla öne çıkan ilk dört anahtar kelimenin sırasıyla Sinema (91), Türk Sineması (62), film (25) ve sinema tarihi (15) olduğu tespit edilmiştir (Tablo 6). Tezlerin yarıdan fazlasını oluşturan Türk sineması konusuna olan eğilim anahtar kelimelerde de kendini göstermektedir. Sinema tarihine olan artan ilgi de anahtar kelimelerde ayrıca belirmektedir.

Tablo 7: En Sık Kullanılan Anahtar Kelimeler

\begin{tabular}{|l|l|l|}
\hline Anahtar Kelimeler & $\mathbf{n}$ & $\%$ \\
\hline Sinema & 91 & 47,15 \\
\hline Türk Sineması & 62 & 32,13 \\
\hline Film & 25 & 12,95 \\
\hline Sinema Tarihi & 15 & 7,77 \\
\hline Toplam & 193 & 100 \\
\hline
\end{tabular}


Son olarak da araştırmaların hangi dilde kaleme alındıkları incelendiğinde, tezlerin \%90,95 oranında (181) Türkçe olarak yazılmış olduğu görülmüştür (Tablo 7). Geriye kalan tezlerin kullandığı yabancı diller \%7,04 (14) İngilizce, \%1,51 (3) Fransızca, \%0,5 (1) Almanca'dır. Yabancı dillerde kaleme alınmış olan bu 18 tezin 16 'sının yine 2000 yılından sonra tamamlandığı görülmüş olup; bunların hemen hepsi yabancı diller, mimarlık gibi diğer akademik alanlarda yapılmış sinema araştırmalarıdır.

Tablo 8: Tezlerin Yazıldıkları Diller

\begin{tabular}{|l|l|l|}
\hline Dil & $\mathbf{n}$ & $\mathbf{\%}$ \\
\hline Türkçe & 181 & 90,95 \\
\hline İngilizce & 14 & 7,04 \\
\hline Fransızca & 3 & 1,51 \\
\hline Almanca & 1 & 0,50 \\
\hline Toplam & 199 & 100 \\
\hline
\end{tabular}

\section{Tartışma ve Sonuç}

Türkiye'de 1985-2013 yıları arasında tamamlanmış doktora ve sanatta yeterlilik düzeyindeki tezlerin bibliyometrik bir çözümlemesinin yapıldığı bu çalışmayla üniversitelerdeki lisansüstü sinema araştırmalarının genel özellikleri ve yönelimleri ortaya konulmaya çalışımıştır.

Araştırma sonucunda sinema araştırmalarında hem nicelik hem çeşitlilik bağlamında açık bir canlanmanın olduğu görülmektedir. 2000'li yıllarla beraber sinema araştırmalarının sayısında önemli bir artışın başladığı, bu artışın son yıllarda giderek hızlandığı, yaklaşık otuz yıllık bir zaman dilimine yayılan tezlerin yaklaşık yarısının son beş yılda yazıımış olmasından anlaşılmaktadır.

Bunun yanında yeni konu ve yaklaşımların denenmeye çalışıldığı, sinema araştırmalarının daha disiplinler arası bir nitelik kazanma yöneliminde olduğu tespit edilmiştir. Bu yönelim 1990'ların ortasında başlayarak gelişmekle birlikte 2000 'lerden itibaren ivmelenmiştir. Farklı disiplinlere bağlı anabilim ve anasanat dallarında çalışan araştırmacıların sinema araştırmalarına olan ilgisinin gün geçtikçe artmakta olduğu görülmektedir. Başlangıçta yalnızca edebiyat, grafik gibi sinemayla öteden beri yakın ilişki içinde olduğu bilinen araştırma alanlarından sinema tezlerine rastlanırken; 2008'den itibaren felsefe, hukuk, işletme, ilahiyat gibi daha uzak kabul edilebilecek akademik disiplinlerde de sinemayı ele alan doktora araştırmalarına yönelindiği görülmektedir. 
Dünyada başlangıçta disiplinler arası bir özellik gösteren, özellikle farkı disiplinlerden getirilen yöntemlerin uygulandığı bir alan olarak ortaya çıkan sinema araştırmaları, daha sonra kendi terminolojisini ve yöntemlerini oluşturduğu bir döneme girmişti. Son yıllarda ise yeniden diğer disiplinlerle bir yakınlaşma süreci içine girilerek disiplinler arasılığın yükseliş gösterdiği bir dönem oluşmuştur (Altman 2009: 135; Andrew 2000: 348-349). Bu küresel eğilim Türkiye'deki sinema araştırmalarında da yansımasını bulmaktadır. İlk dönemin psikanaliz ve göstergebilim gibi modernist tabir edilen klasikleşmiş teori ve yöntemlerinin uygulama ve geliştiriminden çok, yeni bakış açılarının gündeme geldiği bir genişleme söz konusudur. Örneğin, 2000'li yıllarla birlikte Batıdaki kuramsal ve eleştirel çalışmalardan da etkilenerek felsefenin, bilişsel çalışmaların, postmodernizm tartışmalarının sinema çalışmalarının disiplinler arası niteliğine katkıda bulunduğuna tanık olunmaktadır. İzleyici araştırmaları açısından 1980'lerde yapılan 2 araştırmaya karşılık 1990'larda herhangi bir örneğe rastlamazken, 2000'lerde yeniden bir hareketlenme görülmektedir.

Sinema araştırmalarının en temel konusu olan biçim ve biçem sorunlarından çok toplumbilimsel bakış açılarının baskınlığının araştırmalarda kendisini hissettirmesi, disiplinler arası yönelimin en temel göstergelerinden biri olarak kabul edilebilir. Bu durum, alanın çeşitliliği ve zenginleşmesi açısından önemli bir özellik olarak nitelendirilebilir. Toplumbilimle iç içe geçmesi nedeniyle ideoloji, feminist ve toplumsal cinsiyet yaklaşımları da toplumbilimsel yaklaşım grubuna dâhil edildiğinde, alt dallarıyla birlikte toplumbilim kaynaklı yaklaşımların \%39,19'luk önemli bir payı temsil ettiği görülmektedir.

Dikkate değer bir başka sonuç, Türkiye sinemasının yıldan yıla daha fazla sayıda doktora araştırmacısının ilgisini çekmiş olduğudur. 2000'li yıllarda yerli sinema üzerine olan tezlerin sayısındaki artışı açıklayabilecek en önemli olgu, film yapım sektöründeki canlanmadır. Yıldan yıla farklılıklar göstermekle birlikte yerli film üretimi ve seyirci sayısı bu dönemde önemli ölçüde artmıştır. 1999'dan 2009'a yerli film izleyici sayısı yaklaşık yedi katına çıkmıştır ve bu toplam izleyicinin yarısından fazlasını oluşturmaktadır (Gürata 2010: 133). Doktora araştırmacılarının tez konusu seçimlerinde de bu duruma uygun bir eğilim gözlenmektedir.

En fazla sayıda doktora ve sanatta yeterlilik çalışması eleştiri ve çözümleme temel alanında gerçekleştirilmiştir. Diğer yandan, görece bir artışa rağmen, sinema kuramı, sinema tarihi gibi alanlardaki araştırmalar halen sınırlı oranlarda kalmaktadır. Belgesel, deneysel ve canlandırma sinemalarına yönelik ilginin de son yıllarda canlanmaya başladığı tespit edilmiş olmasına karşın; bunların halen inmal edilmiş alanlar arasında yer aldıkları söylenebilir. 


\section{Kaynakça}

ALTMAN Rick R. (2009), "Whither film studies (in a post-film studies world)?", Cinema Journal, Sayı: 49(1): 131-135, doi:10.1353/cj.0.0160

ANDREW Dudley (2000)," "Three Ages" of Cinema Studies and the Age to Come", PMLA, Sayı: 115(3): 341-351.

ANDREW Dudley (2009), "The Core and the Flow of Film Studies", Critical Inquiry, Sayı: 35: 879-915.

EZEMA Ifeanyi J. (2010), "Trends in electronic journal publishing in Africa: An Analysis of African Journal Online (AJOL)", Webology, Sayı: 7(1), http://www. webology.org/2010/v7n1/a74.html, 20.09.2011

BORGMAN Christine L. ve FURNER, Jonathan (2002), "Scholarly Communication and Bibliometrics", Blaise Cronin (der.), Annual Review of Information Science and Technology, Medford-NJ, Information Today, s. 3-72.

BORGMAN Christine L. ve RICE, Ronald E. (1992), "The convergence of information science and communication: A bibliometric analysis", Journal of the American Society for Information Science, Sayl; 43(6): 397-411.

CORONADO Rogelio A., RIDDLE, Daniel L., WURTZEL, Wendy A. ve GEORGE, Steven Z. (2011), "Bibliometric Analysis of Articles Published from 1980 to 2009 in Physical Therapy", Journal of the American Physical Therapy Association,Physical Therapy, Sayı: 91(5): 42-655.

ELSAESSER Thomas ve BUCKLAND Warren (2002), Studying Contemporary American film : A Guide to Movie Analysis, London-Arnold-New York, Oxford University Press.

FEELEY Thomas H. (2008), "A Bibliometric Analysis of Communication Journals from 2002 to 2005", Human Communication Research, Sayı: 35(3): 505-520.

GRIEVESON Lee (2009), "Discipline and Publish: The Birth of Cinematology", Cinema Journal, Sayı: 49(1): 168-175.

GÜRATA Ahmet (2010), "2000'li Yıllarda Sinemaya Bir Bakış", Sinecine Sinema Araştırmaları Dergisi, Sayı: 1(1): 131-135.

NARIN Francis (1976), Evaluative Bibliometrics: The Use of Publication and Citation Analysis in The Evaluation of Scientific Activity, New Jersey, Computer Horizons Inc.

OKAY Aydemir ve OKAY Ayla (2008a), “Undergraduate and Graduate Public Relations Education in Turkey: A Quantitative Study of Dissertations Contributions to Public Relations Field (1984-2007)", Selçuk İletişim, Sayı: 5(2): 5-14.

OKAY Aydemir ve OKAY Ayla (2008b), "MA And Doctoral Public Relations Research in Turkey (1984-2007): A Quantitative Study of Dissertations 
Contribution to Public Relations Field", Public Relations Review, Sayı: 34:312314.

PASADEOS Yorgo, BERGER, Bruceve RENFRO, Bruce R. (2010), “Public Relations as a Maturing Discipline: An Update on Research Networks", Journal Of Public Relations Research, Sayı: 22(2):136-158, doi:10.1080/10627261003601390

PASADEOS Yorgo (1985), "A Bibliometric Study of Advertising Citations", Journal of Advertising, Sayı: 14(4): 52-68.

PRITCHARD Alan (1969), "Statistical Bibliography or Bibliometrics?", Journal of Documentation, Sayı: 25(4): 348-349.

REEVES Byron ve BORGMAN Christine L. (1983), "A Bibliometric Evaluation of Core Journals in Communication Research", Human Communication Research, Sayı:10(1): 119-136.

ROSS Sheletha (2010), "A Bibliometric Study: An Author Analysis of Library Quarterly 1993-2003 (Volumes 63-73)", http://eric.ed.gov/?id=ED511568, 20.06.2013

TURNER Graeme (1999), Film as Social Practice, New York, Routledge.

UÇAK Nazan Ö. ve AL Umut (2009), "The Differences Among Disciplines in Scholarly Communication", Libri, Sayı: 59: 166-179

ÜSDIKEN Bülent ve PASADEOS Yorgo (1995), "Organisational Analysis in North America and Europe: A Comparison of Co-citation Networks", Organisation Studies, Sayl: 16(3):503-526.

YALÇIN Haydar, (2010), "Milli Folklor Dergisi'nin Bibliyometrik Profili (20072009)", Milli Folklor, Sayı: 22(25): 205-211.

YILMAZ R. Ayhan ve UZOĞLU S. (2003), "An Analysis of Thesis and Dissertations on Advertising and Public Relations in Turkey", $1^{\text {st }}$ International Symposium Communication in the Millennium: A Dialogue between Turkish and American Scholars, Austin, Texas, USA, Eskişehir: Anadolu Üniversitesi Yayınları No: 1440: 403-415.

Yükseköğretim Kurulu Başkanlığı (2010), "Yükseköğretim Kurumlarında Hazırlanan Lisansüstü Tezlerin Internet Üzerinden Derlenmesi Hakkında Kılavuz", https://tez.yok.gov.tr/UlusalTezMerkezi/tezTeslimKilavuz.jsp, 04.07.2013 